\title{
Identification of Novel miRNAs in Mouse Embryonic Stem Cells, Embryonic Fibroblasts, and Reprogrammed Pluripotent Cells
}

Botao Zhao ${ }^{1 *}$ and Chunsun Fan ${ }^{2,3,4 *}$

${ }^{1}$ School of Life Sciences, Shanghai University, Shanghai 200444 China

${ }^{2}$ Department of Etiology, the Affiliated Qidong Hospital of Nantong University, Qidong, Jiangsu 226200

${ }^{3}$ Department of Etiology, Qidong People’s Hospital, Qidong, Jiangsu, 226200 China

${ }^{4}$ Qidong Liver Cancer Institute, Qidong, Jiangsu, 226200 China

*Correspondence to Chunsun Fan, Department of Etiology, the Affiliated Qidong Hospital of Nantong University, 785 Jianghai Road, Qidong 226200, China. E-mail: fanchunsun@263.net; Botao Zhao, School of Life Sciences, Shanghai University, 333 Nanchen Road, Shanghai 200444, China. E-mail: zhaobotao@shu.edu.cn.

Running title: Identification of novel miRNAs in mouse 


\section{Abstract}

MicroRNAs (miRNAs) are a class of non-coding small RNAs that function in almost every known cellular activity. MiRNAs play an important role in gene regulation that controls embryonic stem cell (ESC) pluripotency and differentiation, as well as induced pluripotent stem cell (iPSC) reprogramming. In this study, we identified nine novel miRNAs by mining the deep sequencing dataset from mouse embryonic stem cells, mouse embryonic fibroblasts (MEF) and three kinds of reprogrammed pluripotent cells. Most of them are non-conserved but species-specific and cell-specific miRNAs. Eight miRNAs are derived from gene introns, including a "mirtron" miRNA, miR-novel-41. We also showed that miR-novel-27 is a mouse-specific miRNA and the 5' arm of its precursor hairpin, embedding the mature miR-novel-27, uniquely exists in mouse species but not in any other Placentalia animals. Notably, the 5' arm of the pre-miR-novel-27 hairpin shows nearly perfect palindrome to the $3^{\prime}$ arm suggesting that it was generated by inverted duplication of the $3^{\prime}$ arm. By this mechanism, the pre-miR-novel-27 hairpin was de novo gained in the mouse genome. This is a new type of de novo miRNA emergence mechanism in animals, which we called "inverted local half hairpin duplication" here. In addition, very limited nucleotide mutants accumulated on the newly emerged $5^{\prime}$ arm since its birth suggesting an especially young evolutionary history of the miR-novel-27 gene.

Keywords: microRNA, novel miRNA, mirtron, miRNA evolution, miRNA de novo emergence, mouse embryonic stem cells, mouse reprogrammed pluripotent cells 


\section{Introduction}

MiRNAs are endogenous, single-stranded small RNAs ( 22 nt) found in plants, animals and some viruses. They regulate target gene expression at the post-transcriptional level by binding to the complementary sequences within the target mRNAs. In animals, most miRNAs are transcribed from genome DNA sequences into large primary miRNAs (primiRNA) by RNA polymerase II [Lee et al., 2004]. The pri-miRNAs have hairpin structures that are then recognized and processed in the nucleus by the microprocessor complex, consisting of an RNA binding protein DiGeorge Syndrome Critical Region 8 (DGCR8 or "Pasha" in invertebrates) and a ribonuclease III enzyme, Drosha [Denli et al., 2004; Han et al., 2004]. The resulting hairpins are typically 60-100 nucleotides long and are called miRNA precursors (pre-miRNA) [Lee et al., 2003]. The pre-miRNAs are then exported to the cytoplasm by Exportin 5 (Exp5) and Ran-GTP complex [Kim, 2004; Lund et al., 2004; Yi et al., 2003]. In the cytoplasm, the pre-miRNAs are further processed into 22 nucleotides long miRNA duplex by the RNAse III enzyme Dicer [Grishok et al., 2001; Hutvagner et al., 2001]. Then, one strand of the duplexed miRNA is selected and incorporates into the RNA-induced silencing complex (RISC) to function miRNA-guided gene silencing [Iwasaki et al., 2010]. The selection of an active miRNA is primarily based on thermal stability. The strand with lower stability base-pairing of the $2-4$ nt at the 5 ' end preferentially associates with RISC and thus becomes the active miRNA [Frank et al., 2010; Khvorova et al., 2003; Schwarz et al., 2003; Suzuki et al., 2015]. The other strand, termed passenger miRNA or miRNA*, is favored for degradation and accumulates to a lower level 
than the active miRNA [Czech and Hannon, 2011; Yang et al., 2011]. Usually, the ration of mature miRNA/miRNA* is very asymmetric with a discrepancy of $>10,000: 1$ [Liu et al., 2008]. Although the passenger miRNAs keep at a very low level, they still have a functional role in gene regulation [Mah et al., 2010].

To date, thousands of miRNAs have been identified in various organisms through cloning and sequencing or computational prediction. For example, the miRbase records 1,917 miRNAs and 1,234 miRNAs in human and mouse, respectively [Griffiths-Jones, 2004; Kozomara et al., 2019]. Although miRNAs were initially regarded as evolutionarily conserved, many non-conserved, species-specific miRNAs have been discovered particularly by deep sequencing [Bentwich et al., 2005; Zhang et al., 2018]. Most nonconserved miRNAs are expressed in specific cells at a low level and are believed to be evolutionarily young [Fromm et al., 2015; Ruby et al., 2007]. Interestingly, these young miRNAs are rapidly gained and most of them also rapidly lost indicating a rapid evolution of miRNA genes [Lu et al., 2008; Meunier et al., 2013]. In animals, the major source for miRNA birth is through de novo emergence of RNA hairpins from unstructured sequences, which occasionally acquired a promoter to enable successful transcription [Liu et al., 2008; Zhang et al., 2018]. For hairpins generated in introns, they have more chance to evolve to novel miRNA genes because they are innately transcribed along with their host genes and do not need the acquisition of transcription activity. Consistent with this evolution model, most newly identified novel miRNAs are from gene introns [Franca et al., 2017]. Some 
small introns can form pre-miRNA hairpins lacking the lower stem that can bypass the Drosha processing [Curtis et al., 2012]. These short intron derived miRNAs, called "mirtrons", are confirmed in Drosophila melanogaster and C. elegans, and mammals [Babiarz et al., 2008; Berezikov et al., 2007; Curtis et al., 2012; Ladewig et al., 2012; Sibley et al., 2012]. Another source of miRNA emergence is local genomic DNA duplication of an existing miRNA gene to generate clustered miRNA gene family [Liu et al., 2008; Zhang et al., 2018]. However, the later miRNA emergence mechanism only explains the miRNA gene family expansion and evolvement but not the de novo birth of the first/progenitor miRNA gene of the family.

Initially, Ambros et al. established a set of criteria to annotate a miRNA, in which the expression of mature miRNA of $\sim 22 \mathrm{nt}$ length is needed to be coupled with the existence of a stable hairpin structure precursor. Here, an ideal hairpin structure precursor must contain at least 16 complementary bases between the putative miRNA and the opposite arm. In addition, the mature miRNA should be phylogenetic conserved. Recently, Fromm et al. updated the miRNA annotation system [Fromm et al., 2015]. They stated that two 20-26 nt long reads from each of the two arms with 2-nt offsets should be detected and the expressed mature miRNA sequences should have 5'-end homogeneity. They further limited the loop size from 8 to $40 \mathrm{nt}$. The phylogenetic conservation criterion was not emphasized because many non-conserved miRNAs had already been validated as mentioned above. However, the ratio of mature miRNA/miRNA* is usually very asymmetric with a 
discrepancy of $>10,000: 1$ [Liu et al., 2008]. It would be hard to detect miRNA reads from both arms especially if the miRNA expresses at a relatively low level. In this case, the expressed miRNA with no miRNA* read can still be considered as a miRNA candidate if they derive from an ideal hairpin structure [Axtell et al., 2011]. In this study, we applied the latest updated miRNA annotation criteria to successfully identified nine novel miRNAs in mouse ESCs, MEFs and three kinds of reprogrammed cells. 


\section{Materials and Methods}

Cell samples and RNA data

The deep sequencing dataset was derived from our previous study and had been deposited in the Gene Expression Omnibus repository (www.ncbi.nlm.nih.gov/geo) with an accession number GSE52950 [Zhao et al., 2014]. Mouse embryonic fibroblasts (MEFs) and mouse embryonic stem cells (ESCs) (C57B6/129SvJae F1 strain) were cultured as described [Jiang et al., 2011]. Primary induced pluripotent cells (iPSCs) were established by induction of MEFs carrying dox-inducible four reprogramming factors (Oct4, Sox2, K1f4, and c-Myc). The nuclei of MEFs and iPSCs were transferred to enucleated oocytes to generate nuclear-transferred ESCs (NT-ESCs) and iPSCs (NT-iPSCs). Both ESCs and MEFs generated three replicate RNA samples and each reprogrammed pluripotent cell gave two replicate RNA samples. Total RNAs from these cell samples are subject to deep sequencing by the Solexa platform (BGI-Shenzhen, Shenzhen, China).

\section{Data analysis}

After reads filtration and annotation [Zhao et al., 2014], unannotated small RNA were aligned to the Mouse Genome Assembly (GRCm38/mm10) and their surrounding genomic sequences were extracted for screening the existence of potential pre-miRNA- like hairpin structures by Mireap, a software developed by BGI-Shenzhen (http://sourceforge.net/projects/mireap/). After screening, a raw list containing 689 sequences was generated (Table S1). Because the median reads of all known miRNAs after 
normalization in these samples was 12.6 [Zhao et al., 2014], only small RNAs with normalized average reads more than 12.6 in at least one cell type were considered to be confidently expressed and chosen for this study. The normalization method and factors were the same as those used in our previous studies [Zhao et al., 2014; Zhu et al., 2019]. As the screening by Mireap was conducted just after the sequencing data was produced, some small RNAs in the raw list had already been identified to be miRNAs or other RNA types after that. Thus, further removal of these annotated small RNAs was performed. Then, the remaining sequences were folded by RNAstructure [Bellaousov et al., 2013] and the hairpin structures were manually checked according to the lastest miRNA annotation criteria [Ambros et al., 2003; Fromm et al., 2015]. In detail, a confident novel miRNA should range in size from 20 to $26 \mathrm{nt}$, with detectable expression and a "good" pre-miRNA hairpin structure [Fromm et al., 2015]. In this study, only potential small RNAs more than the median expression level of all known miRNAs were considered to be reliably expressed in these samples. A "good" pre-miRNA hairpin structure criterion used here has at least 16 -nt complementary base-pairing within the miRNA region and both arms separated by a single-stranded loop of 8-40 nt in length [Fromm et al., 2015]. The maximal free energy (MEF) threshold was set at $-25 \mathrm{kcal} / \mathrm{mol}$ to ensure enough hairpin stability. In addition, the miRNA/miRNA* region should not be interrupted by unpaired bubbles larger than 4 nucleotides. The criterion that both arms should be detected was not forced to apply in this study. As mentioned above, the ration of mature miRNA/miRNA* is usually very asymmetric with a discrepancy of $>10,000: 1$ [Liu et al., 2008]. Then, the detection of 
miRNAs from both arms will not be always expected especially if the miRNAs identified have much fewer reads than 10000 . In addition, sequence conservation is omitted due to the fact that many non-conserved, species-specific miRNAs have already been identified and validated [Bentwich et al., 2005; Zhang et al., 2018]. Sequences conservation across species was viewed by UCSC Genome Browser (http://genome.ucsc.edu/) [Kent et al., 2002] and alignment was performed by Clustal X [Jeanmougin et al., 1998]. All long RNAs were folded and presented by RNAfold web server [Gruber et al., 2008]. 


\section{Results}

To identify potential candidate miRNAs, unannotated small RNAs were aligned to the Mouse Genome Assembly (GRCm38/mm10). Their surrounding genomic sequences were extracted and folded as RNA sequences for the potential existence of pre-miRNA-like hairpin structures. 689 potential hairpin structures were identified (Figure S1). Among them, only small RNAs with average normalized reads more than 12.6 (the median reads of all known miRNAs in these samples) in at least one cell type were considered to have confident evidence of expression. After further removal newly identified miRNAs and other small RNAs overlapped with known snoRNAs, exon of protein-coding genes, and so on, a list containing 63 small RNAs was generated. Their potential pre-miRNA hairpin structures were manually checked to ensure to satisfy with the recently updated miRNA annotation criteria [Fromm et al., 2015]. Finally, nine candidates of pre-miRNA hairpins were identified (Table 1) and their structures were presented in Figure 1. All these hairpins are reliably stable with high fold possibility and low folding free energies (Figure $1 \&$ Figure S1). Remarkably, both arms of pre-mir-novel-27 and pre-miR-novel-65 produced mature miRNA sequences (Table 1). The 2-nt 3'overhang between the two miRNAs and their miRNA* sequences indicated a typical Drosha/Dicer processing character (Figure 1). Taken together, all the evidence strongly supported that these hairpins are bona fide precursors of miRNAs. Consistent with the previous evolution model, seven of the nine miRNA hairpins derive from the gene introns indicating a high ratio of intron derived miRNAs (Table 1) [Franca et al., 2017]. 
Then, we searched these small RNAs against the initial 689 small RNAs to include their diverse sequences with different 5'- or 3'- ends. Four miRNAs, miR-novel-12, miR-novel20, miR-novel-41 and miR-novel-81, had diverse reads with different 3 '- ends, and yet, all the diverse reads of each miRNA had 100\% 5'-end homogeneity (Table 2). After combining these diverse reads, miR-novel-10 showed the highest expression with 471 total reads in all samples, followed by miR-novel-12 with 400 total reads and miR-novel-16 with 340 total reads, respectively. Interestingly, most of these miRNAs dominantly expressed with more than half reads in one cell type (Table $2 \&$ Figure 2). Four novel miRNAs (miRnovel-10, miR-novel-20, miR-novel- 41 and miR-novel-83) were dominantly expressed in mouse ESCs. MiR-novel-12, miR-novel-16, and mir-novel-81 showed high abundance in iPSCs. MiR-novel-27 and miR-novel-65 mostly expressed in MEFs and NT-ESCs, respectively (Table $2 \&$ Figure 2). The normalized reads in all samples were listed in Table S2.

As mentioned in Table 1, miR-novel-20 overlaps with the exon of GM28592, a predicted lncRNA gene. To date, there is no functional information reported about this lncRNA. Very limited data in Expression Atlas shows that GM28592 expresses at a low level in the mouse brain, liver, and epidermal ectoderm at embryonic day 9.5 (https://www.ebi.ac.uk/gxa). To avoid mis-annotation, we checked that if the hairpin structure of pre-miR-novel-20 could be stably formed in the context of the full-length RNA of GM28592. As shown in Figure 
3, the full-length of GM28592 RNA can form the intact pre-miR-novel-20 hairpin with a very high probability that could serve as a substrate of the miRNA microprocessor complex. Combining with the miR-novel-20 reads detected in this study, we concluded that GM28592 is more likely a miRNA gene although it may also function as a lncRNA.

MiR-novel-41 derives from the intron of Man2c1, a protein-coding gene (Table 1). The host intron is 79-nt and could perfectly fold into a pre-miRNA hairpin structure from which miR-novel-41 is produced (Figure 4). The formed hairpin structure lacks the lower stem part, a typical feature for bypassing the Drosha processing (Figure 4). Mammalian mirtrons predominantly produce mature miRNAs from the $5^{\prime}$ arm. In these cases, the corresponding 3' region is particularly pyrimidine-rich. Consistently, miR-novel-41 also comes from the $5^{\prime}$ arm and there is a very high ration of $\mathrm{C}$ and $\mathrm{U}$ throughout the $3^{\prime}$ arm, especially in the miR-novel-41 complementary region (Figure 4). With these typical characteristics, miRnovel-41 was confidently considered as a mirtron miRNA here. In addition, miR-novel-41 starts at the second nucleotide on the $5^{\prime}$ arm indicating it is a $5^{\prime}$ tailed-mirtron [Curtis et al., 2012].

It has been extensively validated that there are many non-conserved, species-specific miRNAs [Bentwich et al., 2005; Zhang et al., 2018]. To check the sequence conservation of novel miRNAs identified in this study, the pre-miRNA sequences were aligned across Placentalia animals by UCSC Genome Browser (http://genome.ucsc.edu/) [Kent et al., 
2002]. Pre-miR-novel-20 and pre-miR-novel-41, especially their seed sequences, show well conservation in most Placentalia animals. For pre-miR-novel-65 and pre-miR-novel83, although they show somewhat conservation in some Euarchontoglires animals, their mature miRNAs are not conserved. Four miRNA precursors, pre-miR-novel-10, pre-miRnovel-12, pre-miR-novel-16, and pre-miR-novel-81, only show high conservation within Murinae animals, so do their mature miRNAs. Interestingly, miR-novel-27 is a mousespecific miRNA and does not exist even in rat species. Then we narrowed down the species to Murinae animals, which only include mouse and rat in the UCSC Genome Browser database. As shown in Table 3 and Figure S2, all these novel miRNAs, except for miRnovel-27, are well conserved in mouse and rat. For the seed region, five miRNAs (miRnovel-12, miR-novel-16, miR-novel-41, miR-novel-65, and miR-novel-81) are 100\% conserved between mouse and rat (Table 3 \& Figure S2). Mouse miR-novel-10, miRnovel-16 and miR-novel-85 have 2, 2 and 1 nucleotides different from their rat paralogs, respectively (Table $3 \&$ Figure S2). Four of the five different nucleotides are G/A or C/T substitutions and miRNA seed sequences bearing such type of nucleotides substitution could still bind to the same target sequences because the G:U base-pairing is allowed in miRNA/target binding (Table 3 \& Figure S2). Overall, all these novel miRNAs, except for the mouse-specific miR-novel 27, have conserved miRNA/target gene recognition relationship.

For pre-miR-novel-27, it is very strange that its $5^{\prime}$ arm embedding mature miR-novel-27 is 
unique to mouse species and does not exist in all other Placentalia animals; while the host intron of ZFPM2 gene is highly conserved across these animals (Figure S3). Therefore, RNAs from this location of any Placentalia animals but mouse lack of the $5^{\prime}$ arm sequence and could not form the hairpin structure of pre-miRNA-27 at all (Figure S4). It is not possible that all other animals lost this short sequence but the mouse kept it during evolution. Instead, it is obvious that the mouse genome gained this sequence and this gain event must occur after the split of mouse and rat species. This indicates that miR-novel-27 should be a very young miRNA. To explore how miR-novel-27 originated, we looked close to its precursor hairpin structure and sequence. The stem part of pre-miR-novel-27 shows nearly perfect complementary base-pairing that is much higher than most known miRNAs (Figure 1). Such high base-pairing indicates the existence of a palindromic sequence on its genomic DNA and also suggesting that the de novo emergence of the 5' arm came from a short inverted duplication of the $3^{\prime}$ arm (Figure 5A). RNA from such a palindromic DNA sequence can natively fold as a hairpin structure with a full complementary stem part. As a result, the $5^{\prime}$ arm of the pre-miRNA hairpin was de novo gained. This is a new type of miRNA gene de novo birth mechanism, never revealed before in animals, with miR-novel27 as a supporting example. This mechanism only duplicates the half hairpin and is distinct from the previously demonstrated local genomic DNA duplication of the full sequence of an existing miRNA gene, the major source of miRNA gene family expansion. We called this new miRNA birth mechanism as "inverted local half hairpin duplication" in order to distinguish from the previously demonstrated local duplication of existing miRNA genes 
(full hairpin). Here, we presented the new type of de novo birth and evolution model of the miR-novel-27 gene in Figure 6.

Since pre-miR-novel-27 hairpin emergence, mutants gradually accumulated with the course of evolution, and the hairpin eventually was recognized by the miRNA microprocessor complex and produced the miR-novel-27 duplex (both strands detected in this study) with 2-nt 3' offset. Today, there are only four different nucleotides between the original $3^{\prime}$ arm and the duplicated 5' arm of the pre-miR-novel-27 hairpin, and therefore, the base-paring of the stem part is much higher than most of the known miRNAs (Figure 1). Considering the mutation accumulations on each arm are roughly equal in theory, we could expect that only two nucleotides mutations accumulated on the newly emerged $5^{\prime}$ arm since its birth. This information suggests that this inverted local half hairpin duplication event might occur very recently and further supports that the mouse-specific miR-novel-27 is an especially young miRNA gene. 


\section{Discussion}

Novel miRNAs continue to be discovered throughout animals and plants. More and more miRNAs are found to be non-conserved and usually express in specific species, tissues or cells at a relatively low level. Identifying and studying these novel specific expressed miRNAs will help us to better understand the fine regulation of the cell and life. However, annotating a small RNA as a bona fide miRNA should be cautious to avoid false identification because deep sequencing technology has revealed a massive amount of small RNAs with somewhat similar characteristics to miRNAs. Recently, Fromm et al. updated a uniform system for the annotation of miRNAs [Fromm et al., 2015]. To avoid misannotation, we strictly followed these latest updated miRNA annotation criteria. First, the reads of the nine novel miRNAs were at least more than the median value of all known miRNAs in this deep sequencing dataset. Because deep sequencing data are considered as good evidence for gene expression, the criterion of the confident expression of the newly identified miRNAs was well met in this study. Second, all miRNAs, except for miR-novel16, started with 5'-end U or A, ranged from 20-24 nt. Third, all miRNA reads for each miRNA had 100\% 5'-end homogeneity. Forth, all miRNAs have the typical hairpin characteristics satisfied with the miRNA annotation criteria. For example, the stem region has at least 16-nt complementary base-pairing; the loop sequence is $8-40 \mathrm{nt}$ in length. Fromm et al. also stated that there should be two 20-26 nt long reads expressed from each of the two arms of the hairpin precursor with 2-nt $3^{\prime}$ overhangs. However, the ratio of mature miRNA/miRNA* is usually very asymmetric with a discrepancy of $>10,000: 1$ [Liu 
et al., 2008]. Therefore, it is very hard to get reads for the less abundant miRNA* when the mature miRNA expressed at a low level. Especially, many species- or cell-specific and evolutionally young miRNAs usually expressed at relatively low levels. For this reason, although this criterion is evidence of Drosha/Dicer processing, it was not applied in this study. However, we did identify the miRNA* reads of two novel miRNAs, miR-novel-27 and miR-novel-65, with 2-nt 3' overhangs. In addition, the conservation criterion was not applied too because many non-conserved miRNAs have been robustly validated. In fact, we even found that miR-novel-27 is unique to the mouse species and originated from a recent inverted local half hairpin duplication event. In this case, there is no conservation between species at all. Overall, these nine novel miRNAs are well satisfied with the recently updated miRNA annotation criteria and are backed robust supporting of bona fide miRNAs.

MiRNAs are believed to rapidly evolve and show high frequent birth and death in the course of evolution [Meunier et al., 2013; Zhang et al., 2018]. De novo miRNA emergence started from the formation of a pre-miRNA-like hairpin structure that was eventually to be recognized by Drosha/Dicer. In plants, hairpins commonly generated by inverted duplication of target genes [Allen et al., 2004; Axtell et al., 2011]. In animals, hairpin generally evolved from the initially unstructured sequence in random [Axtell et al., 2011; Zhang et al., 2018]. Another major source for the emergence of new miRNA genes in animals was from local duplication of existing miRNA genes (full hairpin), followed by 
subfunctionalization and neofunctionalization [Zhang et al., 2018]. In this way, miRNA genes expanded to gene clusters to form miRNA families [Zhang et al., 2018]. But, the second mechanism only explains the miRNA expansion and evolvement from an existing miRNA gene but not the de novo birth of the existing miRNA gene itself. So, this mechanism is actually a miRNA family expansion mechanism but not the novel miRNA de novo emergence mechanism. Are there other sources of the de novo miRNA emergence other than from unstructured sequences? Here, we represented a new type of de novo miRNA birth mechanism exampled by the miR-novel-27. This new mechanism is the first example of inverted duplicating a short genomic sequence and form a palindromic sequence in animals, from which an RNA molecular could fold into a full hairpin structure. We called it "inverted local half hairpin duplication" in order to distinguish from the previously demonstrated local duplication of existing miRNA genes (full hairpin). Overall, this study presented a new model of de novo miRNA gene birth mechanism in animals supported by miR-novel-27. 


\section{Acknowledgment}

This work was supported by National Natural Science Funds for Distinguished Young

Scholar (31100570) and the Science and Technology Supporting Program of Jiangsu

Province (BE2013657). This work was also supported by the Central Laboratory for

Translational Medicine of Qidong People’s Hospital. 


\section{References}

Allen E, Xie Z, Gustafson AM, Sung GH, Spatafora JW, Carrington JC. 2004. Evolution of microRNA genes by inverted duplication of target gene sequences in Arabidopsis thaliana. Nat Genet 36:128290.

Ambros V, Bartel B, Bartel DP, Burge CB, Carrington JC, Chen X, Dreyfuss G, Eddy SR, Griffiths-Jones S, Marshall M, Matzke M, Ruvkun G, Tuschl T. 2003. A uniform system for microRNA annotation. RNA 9:277-9.

Axtell MJ, Westholm JO, Lai EC. 2011. Vive la difference: biogenesis and evolution of microRNAs in plants and animals. Genome Biol 12:221.

Babiarz JE, Ruby JG, Wang Y, Bartel DP, Blelloch R. 2008. Mouse ES cells express endogenous shRNAs, siRNAs, and other Microprocessor-independent, Dicer-dependent small RNAs. Genes Dev 22:277385.

Bellaousov S, Reuter JS, Seetin MG, Mathews DH. 2013. RNAstructure: Web servers for RNA secondary structure prediction and analysis. Nucleic Acids Res 41:W471-4.

Bentwich I, Avniel A, Karov Y, Aharonov R, Gilad S, Barad O, Barzilai A, Einat P, Einav U, Meiri E, Sharon E, Spector Y, Bentwich Z. 2005. Identification of hundreds of conserved and nonconserved human microRNAs. Nat Genet 37:766-70.

Berezikov E, Chung WJ, Willis J, Cuppen E, Lai EC. 2007. Mammalian mirtron genes. Mol Cell 28:32836.

Curtis HJ, Sibley CR, Wood MJ. 2012. Mirtrons, an emerging class of atypical miRNA. Wiley Interdiscip Rev RNA 3:617-32.

Czech B, Hannon GJ. 2011. Small RNA sorting: matchmaking for Argonautes. Nat Rev Genet 12:19-31. Denli AM, Tops BB, Plasterk RH, Ketting RF, Hannon GJ. 2004. Processing of primary microRNAs by the Microprocessor complex. Nature 432:231-5.

Franca GS, Hinske LC, Galante PA, Vibranovski MD. 2017. Unveiling the Impact of the Genomic Architecture on the Evolution of Vertebrate microRNAs. Front Genet 8:34.

Frank F, Sonenberg N, Nagar B. 2010. Structural basis for 5'-nucleotide base-specific recognition of guide RNA by human AGO2. Nature 465:818-22.

Fromm B, Billipp T, Peck LE, Johansen M, Tarver JE, King BL, Newcomb JM, Sempere LF, Flatmark K, Hovig E, Peterson KJ. 2015. A Uniform System for the Annotation of Vertebrate microRNA Genes and the Evolution of the Human microRNAome. Annu Rev Genet 49:213-42.

Griffiths-Jones S. 2004. The microRNA Registry. Nucleic Acids Res 32:D109-11.

Grishok A, Pasquinelli AE, Conte D, Li N, Parrish S, Ha I, Baillie DL, Fire A, Ruvkun G, Mello CC. 2001. Genes and mechanisms related to RNA interference regulate expression of the small temporal RNAs that control C. elegans developmental timing. Cell 106:23-34.

Gruber AR, Lorenz R, Bernhart SH, Neubock R, Hofacker IL. 2008. The Vienna RNA websuite. Nucleic Acids Res 36:W70-4.

Han J, Lee Y, Yeom KH, Kim YK, Jin H, Kim VN. 2004. The Drosha-DGCR8 complex in primary microRNA processing. Genes Dev 18:3016-27.

Hutvagner G, McLachlan J, Pasquinelli AE, Balint E, Tuschl T, Zamore PD. 2001. A cellular function for 
the RNA-interference enzyme Dicer in the maturation of the let-7 small temporal RNA. Science 293:834-8.

Iwasaki S, Kobayashi M, Yoda M, Sakaguchi Y, Katsuma S, Suzuki T, Tomari Y. 2010. Hsc70/Hsp90 chaperone machinery mediates ATP-dependent RISC loading of small RNA duplexes. Mol Cell 39:2929. Jeanmougin F, Thompson JD, Gouy M, Higgins DG, Gibson TJ. 1998. Multiple sequence alignment with Clustal X. Trends Biochem Sci 23:403-5.

Jiang J, Ding G, Lin J, Zhang M, Shi L, Lv W, Yang H, Xiao H, Pei G, Li Y, Wu J, Li J. 2011. Different developmental potential of pluripotent stem cells generated by different reprogramming strategies. J Mol Cell Biol 3:197-9.

Kent WJ, Sugnet CW, Furey TS, Roskin KM, Pringle TH, Zahler AM, Haussler D. 2002. The human genome browser at UCSC. Genome Res 12:996-1006.

Khvorova A, Reynolds A, Jayasena SD. 2003. Functional siRNAs and miRNAs exhibit strand bias. Cell 115:209-16.

Kim VN. 2004. MicroRNA precursors in motion: exportin-5 mediates their nuclear export. Trends Cell Biol 14:156-9.

Kozomara A, Birgaoanu M, Griffiths-Jones S. 2019. miRBase: from microRNA sequences to function. Nucleic Acids Res 47:D155-D162.

Ladewig E, Okamura K, Flynt AS, Westholm JO, Lai EC. 2012. Discovery of hundreds of mirtrons in mouse and human small RNA data. Genome Res 22:1634-45.

Lee Y, Ahn C, Han J, Choi H, Kim J, Yim J, Lee J, Provost P, Radmark O, Kim S, Kim VN. 2003. The nuclear RNase III Drosha initiates microRNA processing. Nature 425:415-9.

Lee Y, Kim M, Han J, Yeom KH, Lee S, Baek SH, Kim VN. 2004. MicroRNA genes are transcribed by RNA polymerase II. EMBO J 23:4051-60.

Liu N, Okamura K, Tyler DM, Phillips MD, Chung WJ, Lai EC. 2008. The evolution and functional diversification of animal microRNA genes. Cell Res 18:985-96.

Lu J, Shen Y, Wu Q, Kumar S, He B, Shi S, Carthew RW, Wang SM, Wu Cl. 2008. The birth and death of microRNA genes in Drosophila. Nat Genet 40:351-5.

Lund E, Guttinger S, Calado A, Dahlberg JE, Kutay U. 2004. Nuclear export of microRNA precursors. Science 303:95-8.

Mah SM, Buske C, Humphries RK, Kuchenbauer F. 2010. miRNA*: a passenger stranded in RNAinduced silencing complex? Crit Rev Eukaryot Gene Expr 20:141-8.

Meunier J, Lemoine F, Soumillon M, Liechti A, Weier M, Guschanski K, Hu H, Khaitovich P, Kaessmann H. 2013. Birth and expression evolution of mammalian microRNA genes. Genome Res 23:34 -45.

Ruby JG, Stark A, Johnston WK, Kellis M, Bartel DP, Lai EC. 2007. Evolution, biogenesis, expression, and target predictions of a substantially expanded set of Drosophila microRNAs. Genome Res 17:1850-64. Schwarz DS, Hutvagner G, Du T, Xu Z, Aronin N, Zamore PD. 2003. Asymmetry in the assembly of the RNAi enzyme complex. Cell 115:199-208.

Sibley CR, Seow Y, Saayman S, Dijkstra KK, El Andaloussi S, Weinberg MS, Wood MJ. 2012. The biogenesis and characterization of mammalian microRNAs of mirtron origin. Nucleic Acids Res 40:438 48. 
Suzuki HI, Katsura A, Yasuda T, Ueno T, Mano H, Sugimoto K, Miyazono K. 2015. Small-RNA asymmetry is directly driven by mammalian Argonautes. Nat Struct Mol Biol 22:512-21.

Yang JS, Phillips MD, Betel D, Mu P, Ventura A, Siepel AC, Chen KC, Lai EC. 2011. Widespread regulatory activity of vertebrate microRNA* species. RNA 17:312-26.

Yi R, Qin Y, Macara IG, Cullen BR. 2003. Exportin-5 mediates the nuclear export of pre-microRNAs and short hairpin RNAs. Genes Dev 17:3011-6.

Zhang Y, Yun Z, Gong L, Qu H, Duan X, Jiang Y, Zhu H. 2018. Comparison of miRNA Evolution and Function in Plants and Animals. Microrna 7:4-10.

Zhao B, Yang D, Jiang J, Li J, Fan C, Huang M, Fan Y, Jin Y, Jin Y. 2014. Genome-wide mapping of miRNAs expressed in embryonic stem cells and pluripotent stem cells generated by different reprogramming strategies. BMC Genomics 15:488.

Zhu Y, Fan C, Zhao B. 2019. Differential expression of piRNAs in reprogrammed pluripotent stem cells from mouse embryonic fibroblasts. IUBMB Life. 


\section{Tables}

Table 1. The hairpin sequences of the identified candidate miRNAs.

\begin{tabular}{|c|c|c|c|c|c|}
\hline $\begin{array}{l}\text { Candidate } \\
\text { precursor }\end{array}$ & Sequence & $\begin{array}{l}\text { Reads } \\
\text { distribution } \\
(5 p / 3 p)\end{array}$ & $\begin{array}{l}\text { Length } \\
\text { (nt) }\end{array}$ & $\begin{array}{l}\text { Hairpin } \\
\text { location/strand }\end{array}$ & $\begin{array}{l}\text { Location } \\
\text { description }\end{array}$ \\
\hline $\begin{array}{l}\text { pre-miR- } \\
\text { novel-10 }\end{array}$ & $\begin{array}{l}\text { UGGGGAGGAAUCUGGAAAACAUGGGC } \\
\text { GUGACGUGCAUGGAAGAGAGUGGCGC } \\
\text { CUGUGUCCAGGUUUUCCUUU }\end{array}$ & $471 / 0$ & 72 & $\begin{array}{l}\text { chr3:69593550- } \\
\text { 69593621:- }\end{array}$ & $\begin{array}{l}\text { intron of B3galnt1, } \\
\text { protein coding gene }\end{array}$ \\
\hline $\begin{array}{l}\text { re-miR- } \\
\text { novel-12 }\end{array}$ & $\begin{array}{l}\text { ACCCAUCUUAUGUUAGAAGCUAAGAA } \\
\text { GGGUCAGGCCUGGUUAAUACUUGGAU } \\
\text { GGGAGACAGGACUGACGCUAACUUGA } \\
\text { GUUUUGCCAUUGUGGAU }\end{array}$ & $0 / 400$ & 95 & $\begin{array}{l}\text { chr18:21702467- } \\
21702561:+\end{array}$ & intergenic \\
\hline $\begin{array}{l}\text { pre-miR- } \\
\text { novel-16 }\end{array}$ & $\begin{array}{l}\text { CCCGUGGGCAGGCGCGGAGGCGGGUCC } \\
\text { GCAGAUCCCGAGCGGAGCUUGCCUGGC } \\
\text { GUCUCUGUUUCCGUA }\end{array}$ & $0 / 340$ & 69 & $\begin{array}{l}\text { chr16:13437110- } \\
\text { 13437178:- }\end{array}$ & $\begin{array}{l}\text { intro of GM15738, } \\
\text { predicted lncRNA } \\
\text { gene }\end{array}$ \\
\hline $\begin{array}{l}\text { pre-miR- } \\
\text { novel-20 }\end{array}$ & $\begin{array}{l}\text { AAGGGGUGCUGCUGCUCCGCUCGGCCU } \\
\text { UCAGGCUUCCAGACGCUCCGGCUGGGG } \\
\text { GUAGCAGUAGCAGCCCUG }\end{array}$ & 0 / 292 & 72 & $\begin{array}{l}\text { chr10:111506754- } \\
\text { 111506825:- }\end{array}$ & $\begin{array}{l}\text { exon of GM28592, } \\
\text { predicted lncRNA } \\
\text { gene }\end{array}$ \\
\hline $\begin{array}{l}\text { pre-miR- } \\
\text { novel-27 }\end{array}$ & $\begin{array}{l}\text { CACAAUUUAACUGACAACUGAGUUGA } \\
\text { AGGCAAAGGUAGUAAUGUCUGACUUA } \\
\text { GCUUUGCCUUCAGCUUAGUCGUCAGUU } \\
\text { AAAUUGUG }\end{array}$ & $200 / 1$ & 87 & $\begin{array}{l}\text { chr15:41030830- } \\
\text { 41030916:+ }\end{array}$ & $\begin{array}{l}\text { intron of ZFPM2, } \\
\text { protein coding gene }\end{array}$ \\
\hline
\end{tabular}




\begin{tabular}{|l|l|c|c|l|l|}
\hline $\begin{array}{l}\text { pre-miR- } \\
\text { novel-41 }\end{array}$ & $\begin{array}{l}\text { GUGAGUGGAGACUCGGUAGAGGUAGA } \\
\text { GGUGGGAGUCCUGCCCUUGUCGGUCCU } \\
\text { CAUGGCCUCUCCUGUUCUCCAUCUAG }\end{array}$ & $192 / 0$ & 79 & $\begin{array}{l}\text { chr9:57141916- } \\
57141994:+\end{array}$ & $\begin{array}{l}\text { intron of Man2c1, } \\
\text { protein coding gene }\end{array}$ \\
\hline $\begin{array}{l}\text { pre-miR- } \\
\text { novel-65 }\end{array}$ & $\begin{array}{l}\text { UGGAGCUGAAGAAGCUGAUGGUAGUC } \\
\text { UGGGGCCUCUUAGCCAGAACUGUCAUC } \\
\text { UUCUGUGCCUCCC }\end{array}$ & $103 / 4$ & 66 & $\begin{array}{l}\text { chr13:99508477- } \\
99508542:-\end{array}$ & $\begin{array}{l}\text { intron of Map1b, } \\
\text { protein coding gene }\end{array}$ \\
\hline $\begin{array}{l}\text { pre-miR- } \\
\text { novel-81 }\end{array}$ & $\begin{array}{l}\text { UAUAUGCAUGUGUCUGUAUGAGUGUG } \\
\text { CACACAUGGUAUGCAGGUGUGUGUAC } \\
\text { ACGCCACACAGAGACAGCAUGCA }\end{array}$ & $88 / 0$ & 75 & $\begin{array}{l}\text { chr11:68370523- } \\
68370597:-\end{array}$ & $\begin{array}{l}\text { intron of Ntn1, } \\
\text { protein coding gene }\end{array}$ \\
\hline $\begin{array}{l}\text { pre-miR- } \\
\text { novel-83 }\end{array}$ & $\begin{array}{l}\text { CCUAGACAAAGGGUCACAUUCUGUCGA } \\
\text { AGCGAAUUUGUUAAUAUGAGGCUUUG } \\
\text { GCGGGGUAUGUGGUUCUCUUUCUGGA }\end{array}$ & $0 / 76$ & 79 & $\begin{array}{l}\text { chr19:53019519- } \\
53019597:-\end{array}$ & $\begin{array}{l}\text { intron of xpnpep1, } \\
\text { protein coding gene }\end{array}$ \\
\hline
\end{tabular}


Table 2. The mature sequences of the identified miRNAs.

\begin{tabular}{|c|c|c|c|c|}
\hline Candidate miRNA & Sequence & Length (nt) & $\begin{array}{l}\text { Total } \\
\text { Reads }\end{array}$ & $\begin{array}{l}\text { Reads/most } \\
\text { abundance cell }\end{array}$ \\
\hline miR-novel-10 & AGGAAUCUGGAAAACAUGGGCGU & 23 & 471 & 339 / ES cell \\
\hline $\begin{array}{l}\text { miR-novel-12 } \\
\text { (miR-novel-201) }\end{array}$ & $\begin{array}{l}\text { AGGACTGACGCTAACTTGAGTTTT } \\
\text { AGGACTGACGCTAACTTGAGTTT }\end{array}$ & $\begin{array}{l}24 \\
23\end{array}$ & $\begin{array}{c}374 \\
26\end{array}$ & 197 / iPS cell \\
\hline miR-novel-16 & CGGAGCTTGCCTGGCGTCTCT & 21 & 340 & $151 /$ iPS cell \\
\hline $\begin{array}{l}\text { miR-novel-20 } \\
\text { (miR-novel-181) }\end{array}$ & $\begin{array}{l}\text { UCCGGCUGGGGGUAGCAGUAGC } \\
\text { UCCGGCUGGGGGUAGCAGUAG }\end{array}$ & $\begin{array}{l}21 \\
20\end{array}$ & $\begin{array}{c}264 \\
28\end{array}$ & 167 / ES cell \\
\hline miR-novel-27 & AACUGAGUUGAAGGCAAAGGU & 21 & 200 & 159 / MEF cell \\
\hline $\begin{array}{l}\text { miR-novel-41 } \\
\text { (miR-novel-157) }\end{array}$ & $\begin{array}{l}\text { UGAGUGGAGACUCGGUAGAGGUAG } \\
\text { UGAGUGGAGACUCGGUAGAGGUA }\end{array}$ & $\begin{array}{l}24 \\
23\end{array}$ & $\begin{array}{c}158 \\
34\end{array}$ & 108 / ES cell \\
\hline miR-novel-65 & UGAAGAAGCUGAUGGUAGUCUGG & 23 & 103 & 62 / NT-ES cell \\
\hline $\begin{array}{l}\text { miR-novel-81 } \\
\text { (miR-novel-362) }\end{array}$ & $\begin{array}{l}\text { UGUCUGUAUGAGUGUGCACACA } \\
\text { UGUCUGUAUGAGUGUGCACACAU }\end{array}$ & $\begin{array}{l}22 \\
23\end{array}$ & $\begin{array}{l}77 \\
11\end{array}$ & 47 / iPS cell \\
\hline miR-novel-83 & UUUGGCGGGGUAUGUGGUUCUCU & 23 & 76 & 55 / ES cell \\
\hline
\end{tabular}


Table 3. The sequence similarities of the miRNAs between mouse and rat species. Different nucleotides in the seed region between the two species were indicated by underlined italic fonts.

\begin{tabular}{|c|c|c|c|}
\hline Candidate miRNA & $\begin{array}{c}\text { Precursor similarity } \\
\text { (percentage) }\end{array}$ & $\begin{array}{c}\text { Mature similarity } \\
\text { (percentage) }\end{array}$ & $\begin{array}{l}\text { Seed conservation } \\
\quad(\text { Position 2-8) }\end{array}$ \\
\hline miR-novel-10 & $76 \%$ & $74 \%$ & $\begin{array}{r}\text { Mouse: } \underline{G G A A T C} \underline{T} \\
\text { Rat: } \underline{A G A A T C} \underline{C}\end{array}$ \\
\hline miR-novel-12 & $83 \%$ & $79 \%$ & $\begin{array}{r}\text { Mouse: GGACTGA } \\
\text { Rat: GGACTGA } \\
\end{array}$ \\
\hline miR-novel-16 & $80 \%$ & $86 \%$ & $\begin{array}{r}\text { Mouse: } \underline{G G} \underline{A} G C T T \\
\text { Rat: } \underline{T} G \underline{G} G C T T\end{array}$ \\
\hline miR-novel-20 & $97 \%$ & $100 \%$ & $\begin{array}{r}\text { Mouse: CCGGCTG } \\
\text { Rat: CCGGCTG }\end{array}$ \\
\hline miR-novel-27 & $40 \%$ & -- & -- \\
\hline miR-novel-41 & $94 \%$ & $79 \%$ & $\begin{array}{r}\text { Mouse: GAGTGGA } \\
\text { Rat: GAGTGGA }\end{array}$ \\
\hline miR-novel-65 & $80 \%$ & $83 \%$ & $\begin{array}{r}\text { Mouse: GAAGAAG } \\
\text { Rat: GAAGAAG }\end{array}$ \\
\hline miR-novel-81 & $89 \%$ & $87 \%$ & $\begin{array}{r}\text { Mouse: GTCTGTA } \\
\text { Rat: GTCTGTA } \\
\end{array}$ \\
\hline miR-novel-83 & $63 \%$ & $78 \%$ & $\begin{array}{r}\text { Mouse: TTGGC } \underline{G G} \\
\text { Rat: TTGGC } \underline{A} G\end{array}$ \\
\hline
\end{tabular}




\section{Figure Legends}

Figure 1. Hairpin structures of the candidate miRNA precursors were shown as text format.

Detected mature miRNA sequences were indicated as bold nucleotides. Their reads were

listed in Table 1. Maximal Free Energies (MFE) of the hairpins were listed at left.

Figure 2. Normalized average reads of the candidate miRNAs in each cell type. ES cells:

mouse embryonic stem cells (three replicate samples); MEF cells: mouse embryonic fibroblasts (three replicate samples); NT-ES cells: nuclear-transferred mouse embryonic stem cells (two replicate samples); iPS cells: induced pluripotent cells (two replicate samples); NT-iPS cells: nuclear-transferred induced pluripotent cells (two replicate samples).

Figure 3. The folded full-length RNA of predicted GM28592 gene. The location of the premiR-novel-20 was indicated. The colors of nucleotides showed the base-pairing probability as the scale bar.

Figure 4. MiR-novel-41 is a mirtron miRNA. The sequence of the $25^{\text {th }}$ intron of Man2c1 was underlined. The folded hairpin structure was lack of lower stem part as shown. The mature miRNA-novel-41 sequence was labeled by bold fonts and the pyrimidine nucleotides on the $3^{\prime}$ arm were indicated by asterisks. 
Figure 5. The palindromic sequence of the pre-miR-novel-27 hairpin. The $3^{\prime}$ original arm and $5^{\prime}$ duplicated arm were back-to-back compared and the different nucleotides were boxed out.

Figure 6. The inverted local half hairpin duplication model explained the de novo birth and evolution of the miR-novel-27 gene. The gray sequence indicated the original 3' arm/miRnovel-27* and the light gray sequence indicated the duplicated 5' arm/miR-novel-27.

\section{Supplemental Figure Legends}

Figure S1. The folded structures of the candidate miRNA hairpins. The colors of nucleotides showed the base-pairing probabilities as indicated.

Figure S2. The sequence alignments of the candidate precursors between mouse and rat species. Mature miRNA sequences were indicated with lines at the top, and seed regions were labeled by red boxes.

Figure S3. MiR-novel-27 is unique to mouse species. the surrounding sequence of miRnovel-27 was aligned to other Placentalia animals. The blue shadow indicated the hairpin sequence region. The image was extracted from the UCSC Genome Browser. 
Figure S4. Folded structures of the miR-novel-27 surrounding sequence. (A) The miRnovel-27 precursor sequence was extracted along with the $+/-300$-nt surrounding sequence for RNA structure folding analysis. Pre-miR-novel-27 was stably formed within the indicated context sequence. (B) The RNA sequence use in A was folded again after deleting the duplicated 5' arm region. No pre-miRNA-like hairpin formed throughout the RNA molecular. (C) Sequence from the according region of the rat species was folded and no pre-miRNA-like hairpin formed. Fold probability was scaled as indicated. 
bioRxiv preprint doi: https://doi.org/10.1101/817395; this version posted October 25, 2019. The copyright holder for this preprint (which was not certified by peer review) is the author/funder, who has granted bioRxiv a license to display the preprint in perpetuity. It is made available under aCC-BY-NC-ND 4.0 International license.

\section{Figure 1}

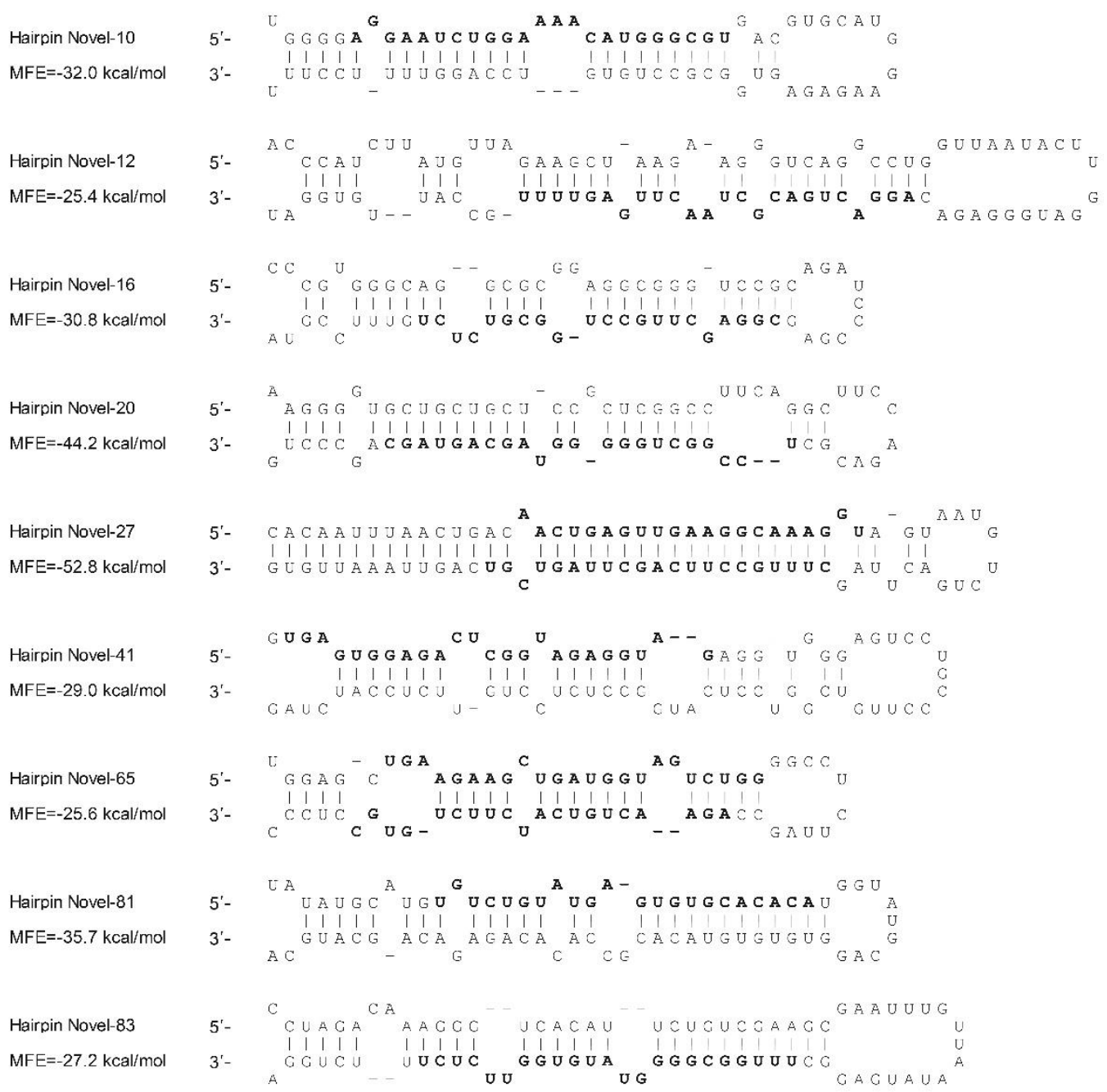

Figure 1 
bioRxiv preprint doi: https://doi.org/10.1101/817395; this version posted October 25, 2019. The copyright holder for this preprint (which was not certified by peer review) is the author/funder, who has granted bioRxiv a license to display the preprint in perpetuity. It is made available under aCC-BY-NC-ND 4.0 International license.

\section{Figure 2}
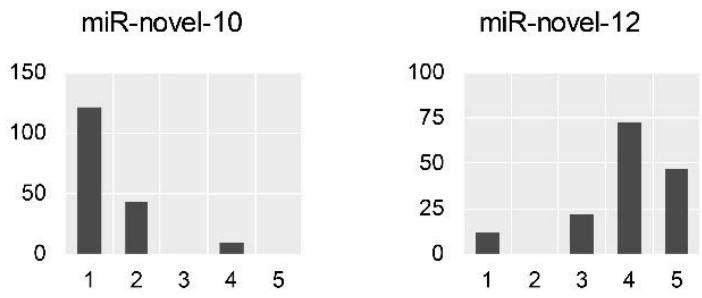

miR-novel-16

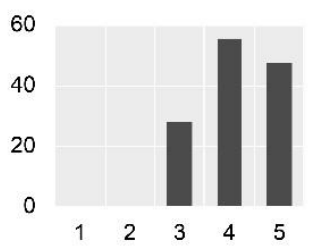

miR-novel-20

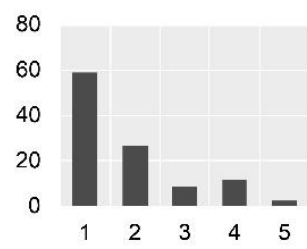

miR-novel-27

miR-novel-41
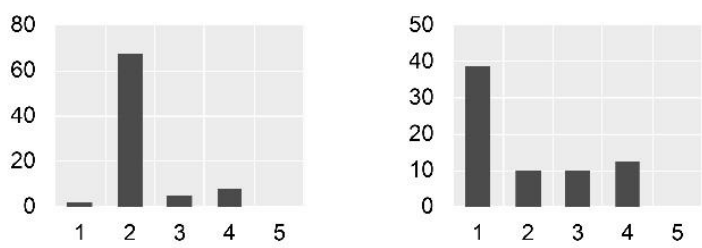

miR-novel-65

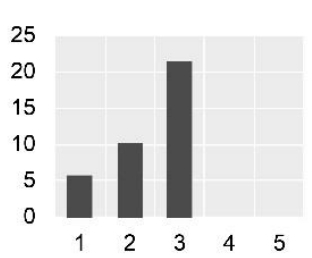

miR-novel-81
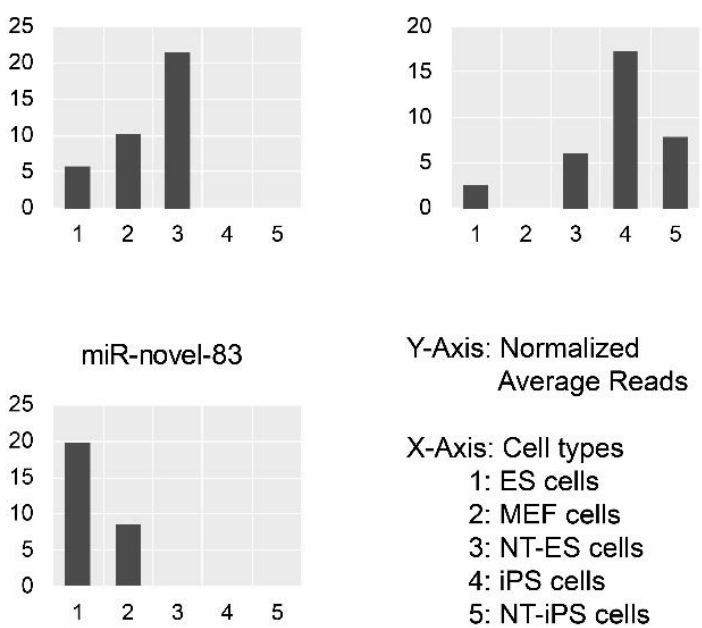

Y-Axis: Normalized Average Reads

X-Axis: Cell types

1: ES cells

2: MEF cells

3: NT-ES cells

4: iPS cells

5: NT-iPS cells

Figure 2 
bioRxiv preprint doi: https://doi.org/10.1101/817395; this version posted October 25, 2019. The copyright holder for this preprint (which was not certified by peer review) is the author/funder, who has granted bioRxiv a license to display the preprint in perpetuity. It is made available under aCC-BY-NC-ND 4.0 International license.

\section{Figure 3}

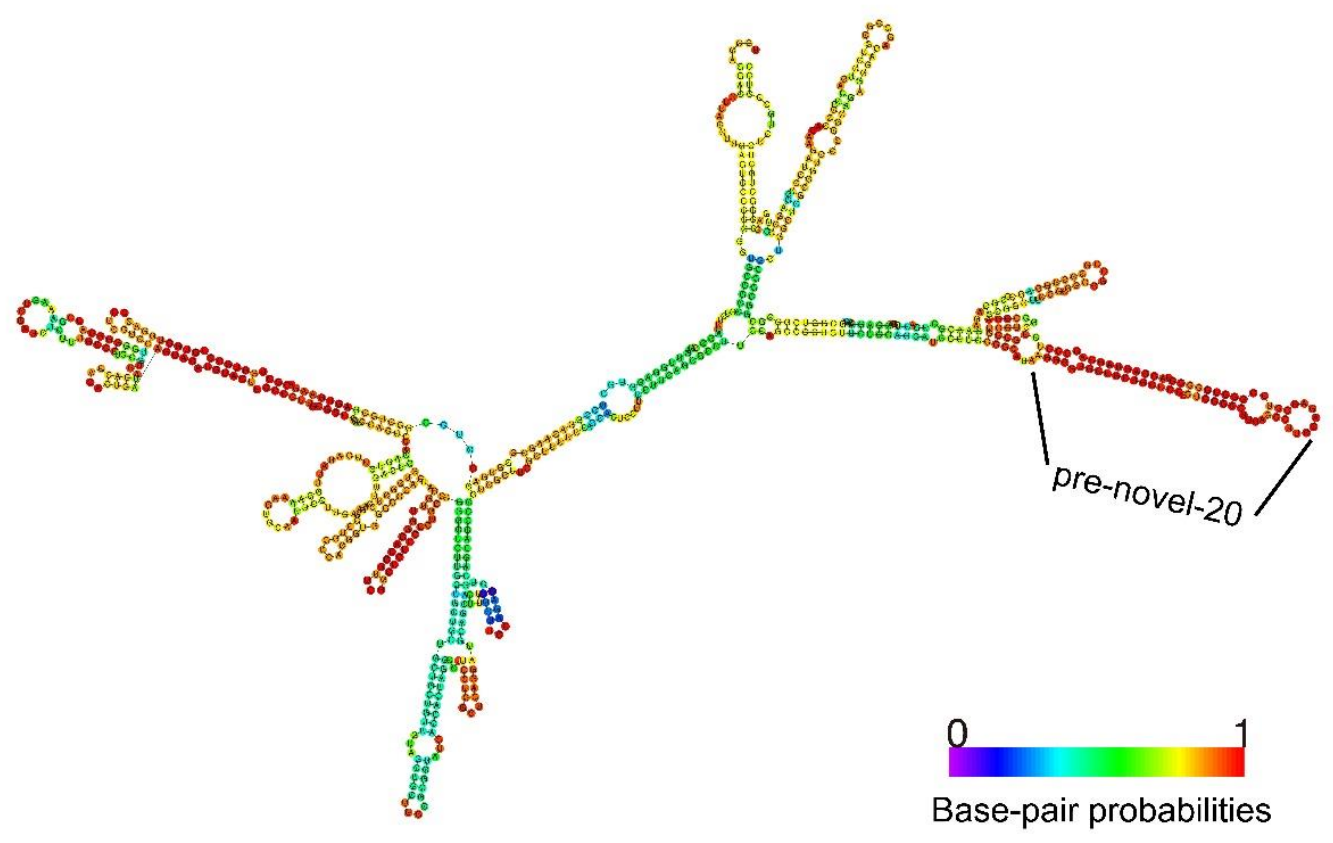

Figure 3 
bioRxiv preprint doi: https://doi.org/10.1101/817395; this version posted October 25, 2019. The copyright holder for this preprint (which was not certified by peer review) is the author/funder, who has granted bioRxiv a license to display the preprint in perpetuity. It is made available under aCC-BY-NC-ND 4.0 International license.

\section{Figure 4}

\section{Man2c1, host protein coding gene}

exon $(25 / 26)$

intron $(25 / 25)$

exon $(26 / 26)$

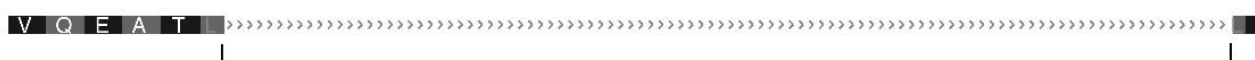

GTTCAGGAGCCCACOCTGTGAGTGGAGACTCGGTAGAGGTAGAGGTGGCAGT CTGOCCTTGTCGGTCCTCATGCDCTCTळTGTTCTOCATCTAGTTGTGACCTCCTGGAG

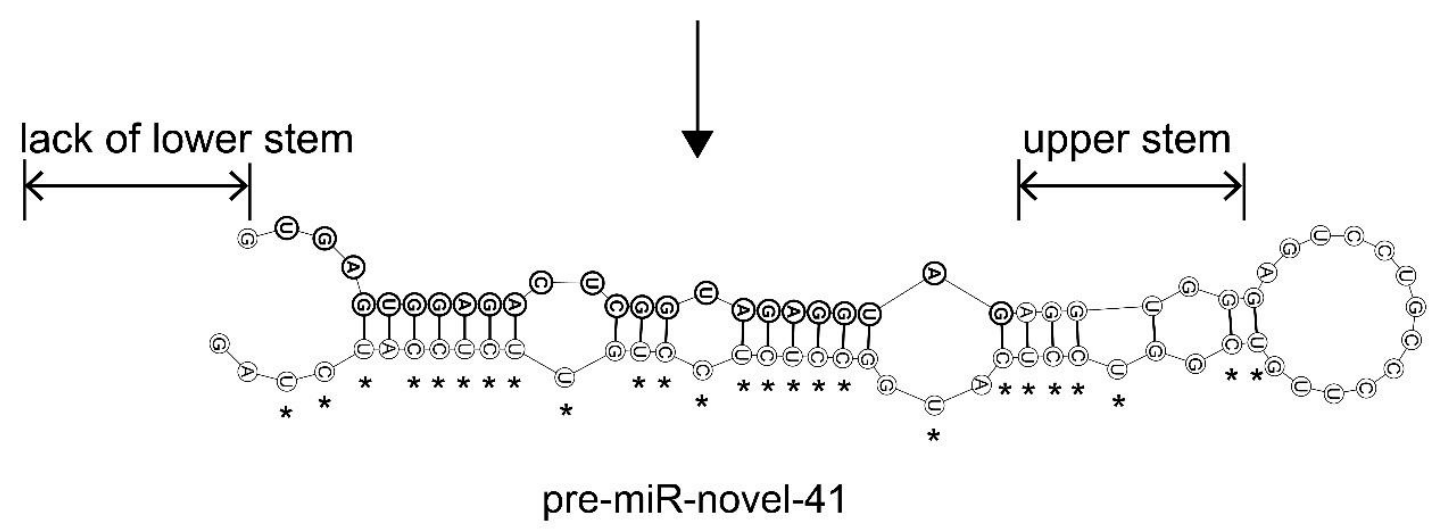

Figure 4 
bioRxiv preprint doi: https://doi.org/10.1101/817395; this version posted October 25,2019 . The copyright holder for this preprint (which was not certified by peer review) is the author/funder, who has granted bioRxiv a license to display the preprint in perpetuity. It is made available under aCC-BY-NC-ND 4.0 International license.

\title{
Figure 5
}

\author{
5' dupicated arm 3' orignal arm
}

5'-CACAATTTAACTGACAACTGAGTTGAAGGCAAAGGTAGTAATGTCTGACTTAGCTTTGCCTTCAGCTTAGTCGTCAGTTAAATTGTG-3'

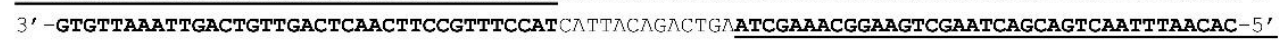
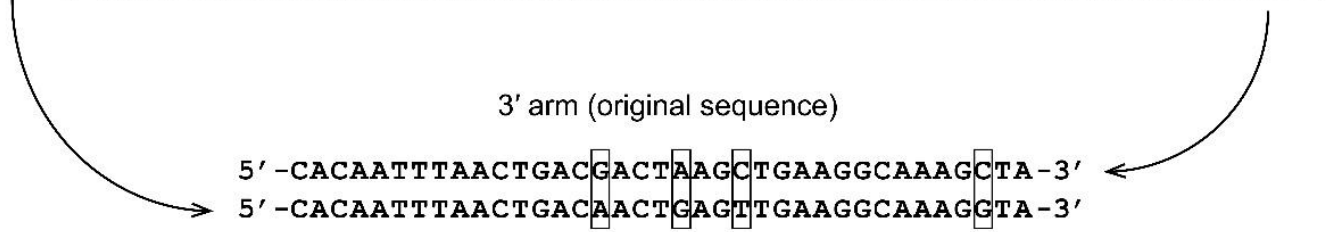

$5^{\prime}$ arm (duplicated sequence)

Figure 5 


\section{Figure 6}

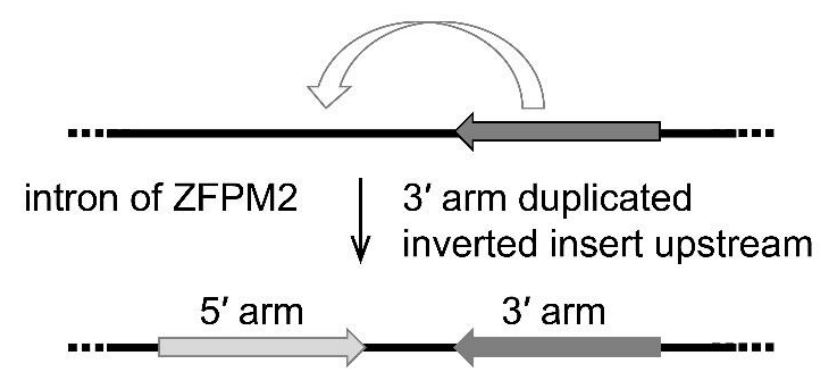
intron of ZFPM2 $\quad$ gain of $5^{\prime}$ arm
form of palindromic sequence
$\downarrow$ host gene transcription

ZFPM2 mRNA

$\downarrow \begin{aligned} & \text { intron splicing } \\ & \text { form of hairpin structure }\end{aligned}$

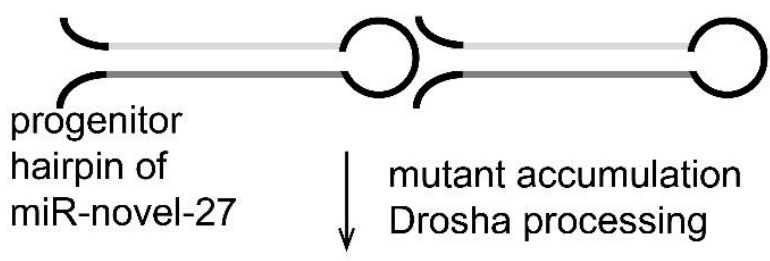

hairpin of

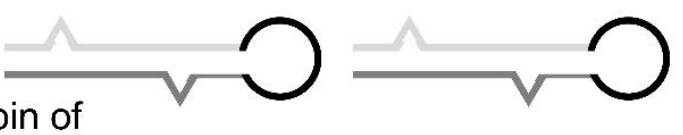

miR-novel-27 $\quad$ Dicer processing
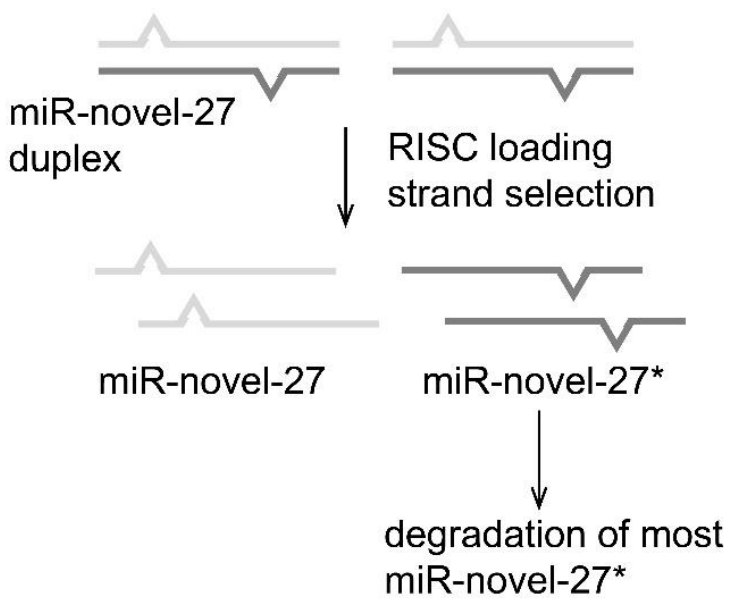

Figure 6 
bioRxiv preprint doi: https://doi.org/10.1101/817395; this version posted October 25, 2019. The copyright holder for this preprint (which was not certified by peer review) is the author/funder, who has granted bioRxiv a license to display the preprint in perpetuity. It is made available under aCC-BY-NC-ND 4.0 International license.

\section{Figure S1}

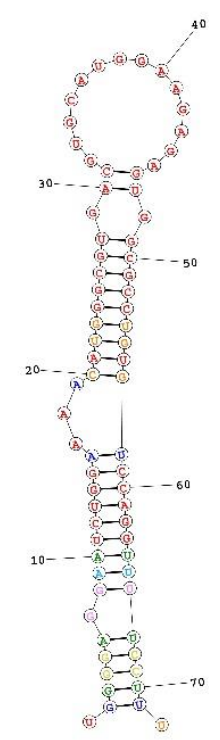

Hairpin Novel-10 $\mathrm{MEF}=-32.0 \mathrm{kcal} / \mathrm{mol}$

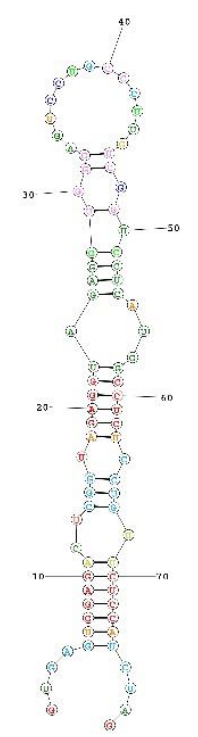

Hairpin Novel-41 $\mathrm{MEF}=-29.0 \mathrm{kcal} / \mathrm{mol}$

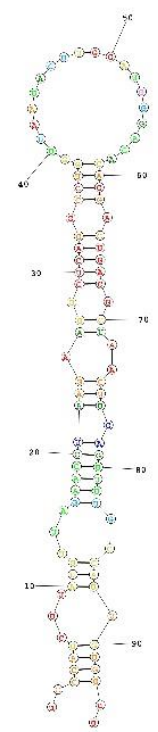

Hairpin Novel-12 $\mathrm{MEF}=-25.4 \mathrm{kcal} / \mathrm{mol}$

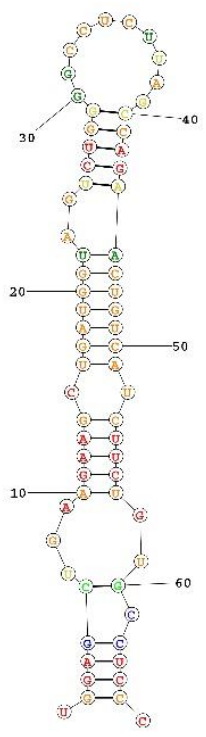

Hairpin Novel-65 $\mathrm{MEF}=-25.6 \mathrm{kcal} / \mathrm{mol}$

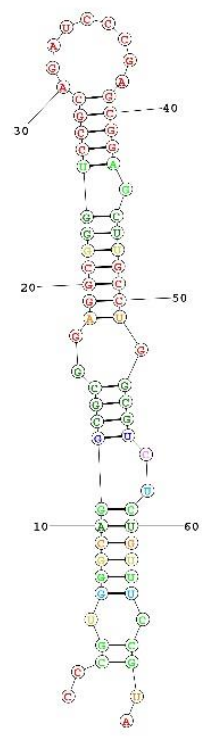

Hairpin Novel-16
$M E F=-30.8 \mathrm{kcal} / \mathrm{mol}$

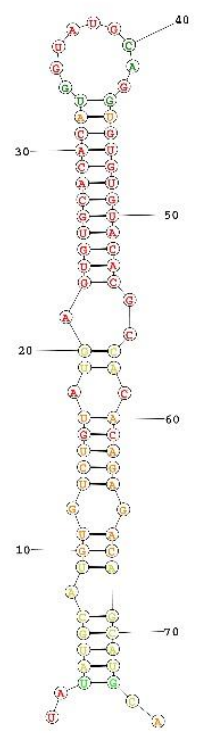

Hairpin Novel-81 $\mathrm{MEF}=-35.7 \mathrm{kcal} / \mathrm{mol}$

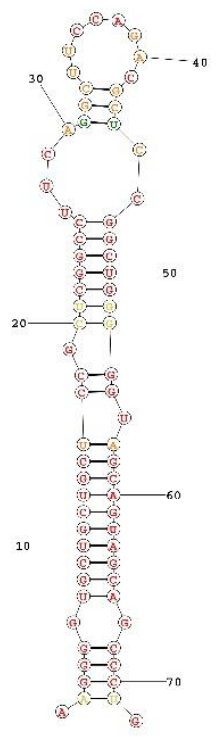

Hairpin Novel-20 $\mathrm{MEF}=-44.2 \mathrm{kcal} / \mathrm{mol}$

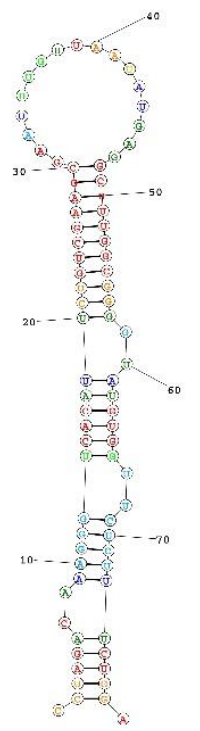

Hairpin Novel-83 $\mathrm{MEF}=-27.2 \mathrm{kcal} / \mathrm{mol}$

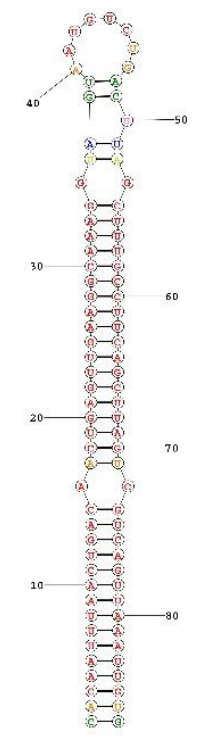

Hairpin Novel-27 $\mathrm{MEF}=-52.8 \mathrm{kcal} / \mathrm{mol}$
Foding Probability Scale

$100 \%>$ Probability $>=99 \%$

$99 \%>$ Probability $>=95 \%$

$95 \%>$ Probability $>=90 \%$

$90 \%>$ Probability $>=80 \%$

$80 \%>$ Probability $>=70 \%$

$70 \%>$ Probability $>=60 \%$

$60 \%>$ Probability > $=50 \%$

$50 \%>$ Probability

Figure $\mathrm{S1}$ 
bioRxiv preprint doi: https://doi.org/10.1101/817395; this version posted October 25, 2019. The copyright holder for this preprint (which was not certified by peer review) is the author/funder, who has granted bioRxiv a license to display the preprint in perpetuity. It is made available under aCC-BY-NC-ND 4.0 International license.

\section{Figure S2}

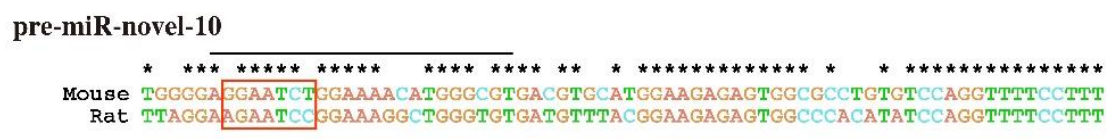

pre-miR-novel-12

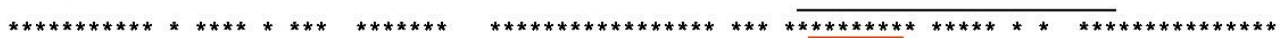

Mouse ACCCATCTTATGTTAGAAGCTAAGAAGGGTCAGGCCTGGTTAATACTTGGATGGGAGACAGGACTGA CGCTAACTIGAGTITTGCCATTGTGGAT Rat ACCCATCTTATCTCAGAACCCAAGT-GGGTCAGTTGTGGTTAATACTTGGATGAGAGGCAGGACTGA CCCTAACATCA-CTTTGCCATTGTGGAT

pre-miR-novel-16

*** $* * * * * * * * * * * * * * * * * * * * * * * \quad * * \overline{* * * * * * * * * * * * * * * * * * * * * * * * *}$

Mouse CCCGTGGGCAGGCGCGGAGGCGGTCCGCAGATCCCGAGCFGAGCTTECCTGGCGTCTCTGTTTCCGTA Rat TCCGCAGACAGGCGCGGAGGCCGGTCGGCACAACCGTAGCTGGGCTTIGCCTGCCGTCTCTGTGTCCGTA

pre-miR-novel-20

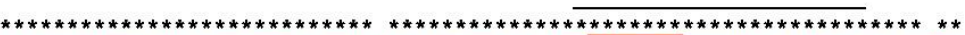

Mouse AAGGGGTGCTGCTGCTCCGCTCGGCCTTCAGGCTTCCAGACGCI CCGGCTGGGGGTAGCAGTAGCAGCCCTG Rat AAGGGGTCTGCTGCTCCGCTCGGCCTTTAGGCTTCCAGACGCTCCGGCTGGGGGTAGCAGTAGCAGCCGTG

pre-miR-novel-27

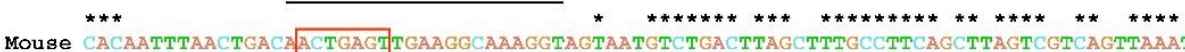
Rat CAC-

pre-miR-novel-41

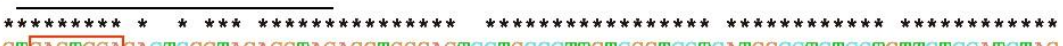

Mouse GT GAGTGGAGACTCGGTAGAGGTAGAGGTGGGATCCTGCCCTTGTCGGTCCTCATGGCCTCTCCTGTTCTCCATCTAC Rat GT GAGTGGA CATACTGTAAAGGTAGAGGTGGGAGCTCTGCCCTTGTCGGTCCTTATGGCCTCTCCTATTCTCCATCTAG

pre-miR-novel-65

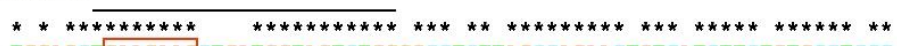

Mouse TGGAGCIGAAGA. CTGATGGTAGTCTGGGGCTCTTAGCCAGAACTGTCATCTTCTGTGCCTCCC

Rat TAGTGCTGAAGAGTGAGGGTAGTCTGGAGCCGCTAAGCCAGAACCGTCTCTTCCGTGCCTTCC

pre-miR-novel-81

* $\quad * * * * * * \overline{* * * * * * * * * * * \quad * * * \quad * * * * * * * * * * * * * * * * * * * * * * * * * * * * * * * * * * * * * * * * * * * * * *}$

Mouse TATATGCATGT GTCTGTATGAGTGTGCACACATGGTATGCAGGTGTGTGTACACGCCACACAGAGACAGCATGCA Rat TGCATGTATGMGTCTGTAT TATTGTATACACATGGTGTGAGGTGTGTGTACACACCACACAGAGACAGCACGCA

pre-miR-novel-83

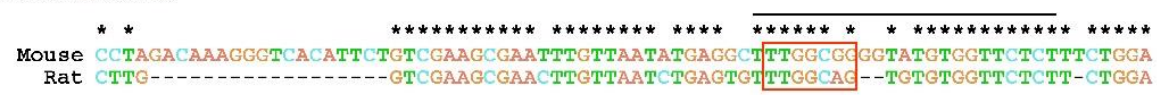

Figure S2 
bioRxiv preprint doi: https://doi.org/10.1101/817395; this version posted October 25, 2019. The copyright holder for this preprint (which was not certified by peer review) is the author/funder, who has granted bioRxiv a license to display the preprint in perpetuity. It is made available under aCC-BY-NC-ND 4.0 International license.

\section{Figure S3}

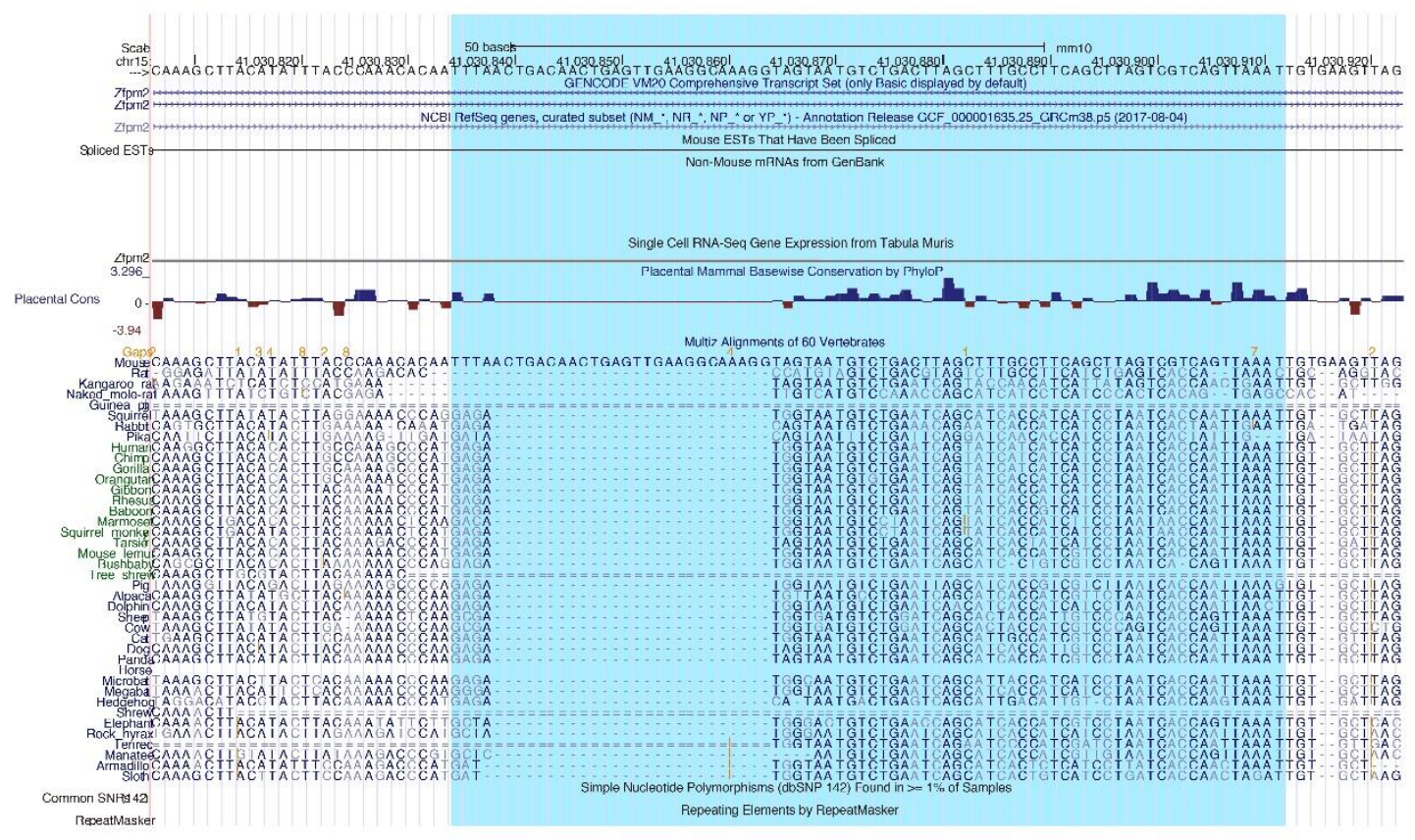

Figure S3 
bioRxiv preprint doi: https://doi.org/10.1101/817395; this version posted October 25, 2019. The copyright holder for this preprint (which was not certified by peer review) is the author/funder, who has granted bioRxiv a license to display the preprint in perpetuity. It is made available under aCC-BY-NC-ND 4.0 International license.

\section{Figure S4}
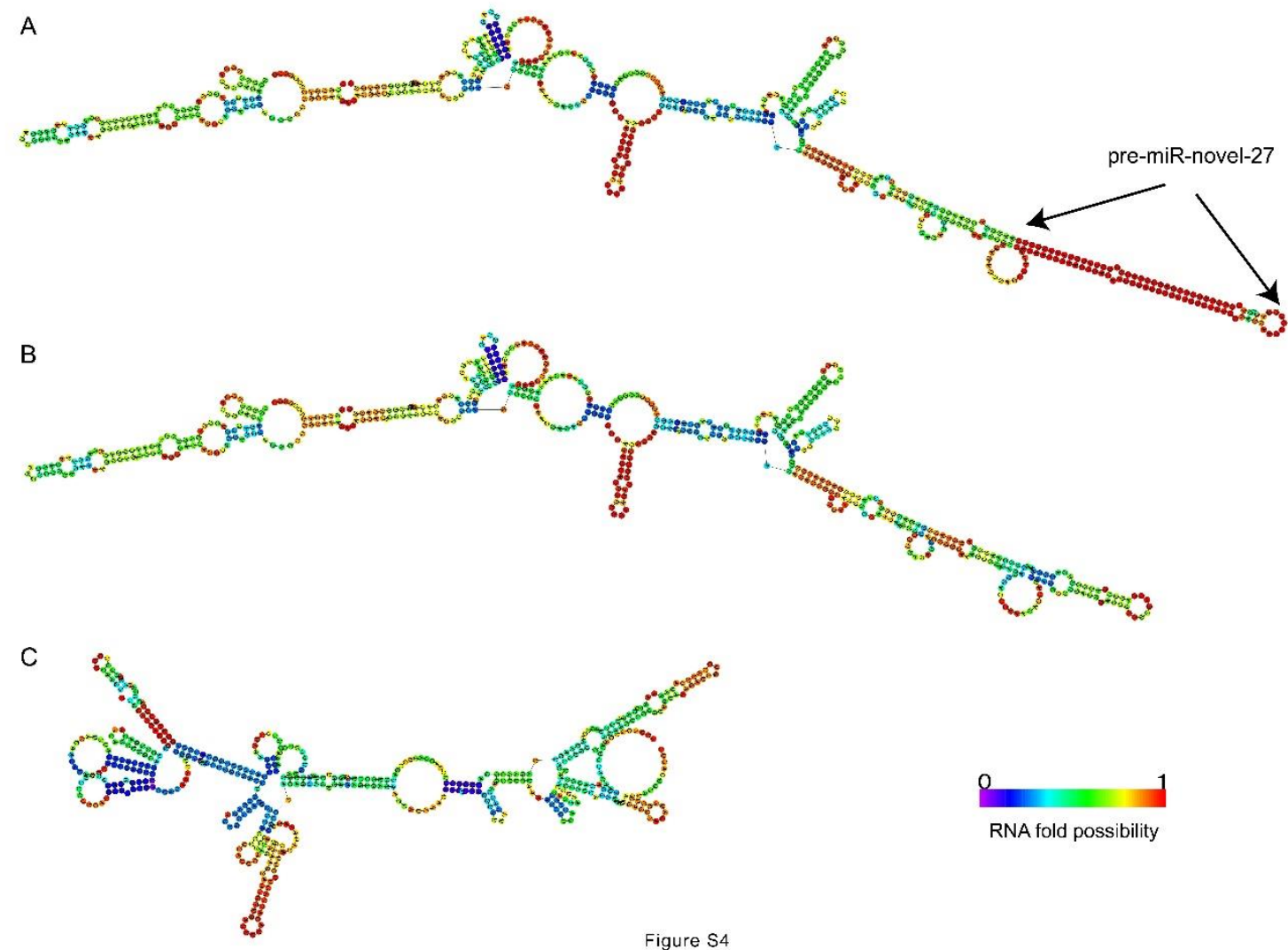